phlets that give an "oversimplified" and "distorted" view of the dangers of nuclear power.

In a report published in Washington last week, the General Accounting Office said that the Breeder Reaction Corporation of Oak Ridge, Tennessee, which represents almost 700 companies involved in the fast breeder programme, had produced a series of thirteen pamphlets about the programme, at least four of which "clearly constitute propaganda and as such are questionable for dissemination to the public".

In particular, the $\mathrm{GAO}$ questioned the statement in one pahphlet that plutonium is "not a realistic threat when compared with other hazardous materials". It says that the pamphlet grossly understates the dangers, and does not inform readers that plutonium is extremely toxic, and in some circumstances carcinogenic.

\title{
US ban use of prisoners in drug research
}

THE US Department of Health, Education and Welfare is planning to ban the use of prisoners for drug research not directly related to their health or well-being.

This suggestion follows last year's report of the Commission for the Protection of Human Subjects of Biomedical and Behavioural Research, suggesting stringent conditions on such research to ensure that the participatin of prisoners was voluntary.

In its response to comments on the Commission's report, published last week (January 6), the department says that the Commission found "a paucity of evidence" that research testing of drugs involving minimal risk on prisoners was necessary (see p. 197).
In issuing proposed regulations on research involving prisoners, the department has therefore suggested that the use of prisoners for biomedical and behavioural research studies other than those relating directly to the causes and conditions of their imprisonment, and their well-being in prison, should be banned.

"The Department has concluded that the need to assure that research on human individuals is performed only o human subjects is performed only on indiviuals who have knowingly and voluntarily consented to participate far outweighs any need that has been shown for the use of prisoners in these studies" it says.

David Dickson
THE high rate of rickets in children of Asian origin in Britain is causing concern, and a demand that the government "does something about it". One suggestion is that various foods including the flour used to make chapatis, should be fortified with vitamin $D$. This proposal is being resisted by some scientists, because the present addition of calcium and vitamins to bread, and of vitamins to margarine, is now under attack. It is pointed out that there is little or no evidence that this costly and complicated scheme is having any beneficial effect on the nutritional standards of the population, and that more experimental evidence should be sought. It is probable that if every Asian child in Britain took a spoonful of codliver oil daily, rickets would disappear among this section of our population. Efforts to ensure that the vitamin went where it was needed would be more effective than giving everyone unnecessary and unwanted supplements.

Those who favour more mass fortification of food have the mistaken belief that as we all need small amounts of substances like vitamin D to preserve our health, then the more we consume of them the healthier we will become. This false opinion is perpetuated by many advertisements. I have before me one which tells me this preparation is rich in protein, iron and vitamins $\mathbf{B} 1$ and $\mathbf{B} 2$. It goes on to say that protein is essential for growth and bodily repairs, iron to nourish the blood, and the vitamins to aid digestion, convert food to energy and to maintain tissues such as nerves, muscles and the skin, and generally to promote "vitality". Seed

\section{Enough is enough}

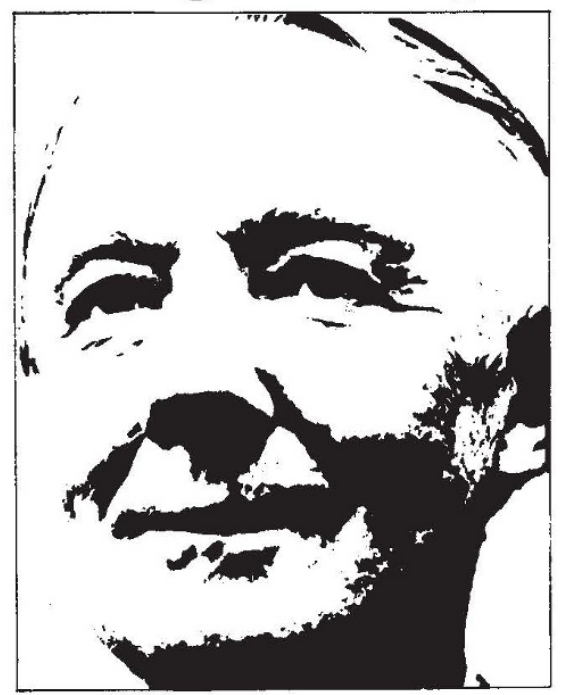

KENNETH MELLANBY

merchants tell us that the more expensive varieties of vegetables give plants particularly full of protein, and with extra amounts of vitamin $\mathrm{C}$ and minerals. Once again they claim that these substances must be taken if we are to remain healthy.

All these statements about the need to eat protein and vitamins are of course true, and if we were living on deficient diets the advertised commodities would no doubt do us good. But when our diet contains the required minimum of these substances, and addition is generally useless and often harmful.

Unfortunately in Britain it is often the better educated who talk the most nonsense about diet. They have learned some of the elements of nutrition and know all about deficiency diseases. They seldom realise that most of our over-fed adults have a surplus of protein and other essentials, and that most of the allegedly health-giving supplements would be best flushed down the drain.

Yet malnutrition, in various forms, is common. In all Western countries the most common and obvious form is gluttony with consequent obesity. Those who try to slim by eating less are subject to a barrage of advertisements for low-calorie foods containing large amounts of supplements. These are generally unnecessary, for the slimmer lives on a nutritious diet of (his own) human flesh. Then the appalling state of our teeth is a symptom of some dietary inbalance, partly but not entirely connected with our overconsumption of sugar. But on the whole most adults seem not to be short of protein and vitamins, so more of these are not "good for them". The only common deficiency would seem to be fibre, and there is evidence to suggest that added bran does some good, but most supplements seem to be useless or harmful.

The position with young children and the elderly is rather different. These groups have a limited food intake, and in Britain today up to half of their calories may come from sugar, in sweetmeats for children, in hot sweet tea for the old. This leaves little room for essential nutrients, so it may be necessary to add these in concentrated form. But it would be more sensible to cut down on the sugar, which, in excess, is always harmful. 